\title{
GUDS ORD besunget af Grundtvig
}

\author{
Ved Uffe Hansen
}

"Herrens Ord er forsvundet af hans Hus, thi naar det og lyder, er det ikke det, som høres, ikke det, som udlægges og indskærpes, det maa lade sig forvende og bruge til hos den enfoldige at styrke Menneskers Mening."

Af Grundtvigs Dimisprædiken 1810.

\section{Grund-Ordet}

Allerede ved begyndelsen af sin præstegerning var Grundtvig klar over, at det af alle i den lutherske kirke anerkendte grundlag for kristendommen, Guds ord, ikke var noget eentydigt begreb.

Det er ikke uden videre lig bibelen, for dens ord kan forvendes og fordrejes, som det ofte blev det af den tids rationalistiske præster. Eller det kan læses med tørre øjne og kritisk sind, og så er det ikke længere Guds ord. Det udvortes kendetegn, at det står i bibelen, er ikke nok; hvis det ikke forkyndes $\mathrm{i}$ ånd og med kraft, er det dog ikke Guds ord. Så fattes det indre kendetegn for Guds ord: at det trænger ind til marv og ben og griber mennesker i deres inderste.

Grundtvig kunne nok i julesangen fra 1810, "Dejlig er den Himmel blaa", tale om "hans Guddoms-Ord det klare". Men han måtte dog livet igennem kæmpe for at vinde klarhed over, hvordan det kan erkendes, hvad det virker, også - men det er mindre vigtigt - hvordan det skal forstås.

De vigtigste resultater af denne hans kamp er at finde $i$ hans salmer, der ved gudstjenesten sætter levende og virksomt ind som et led i opklaringen af denne gåde, at Guds ord kan skabe 
liv og give kraft til dem, der modtager det med åbent sind til tro og lydighed. Herom skriver han i "Krønike-Riim til Børne-Lærdom " 1829, no. LII et digt, som han senere omarbejdede til Sang-Værk I, 1. Heri lader han den kristne kirke selv udtale sig:

v. 10: Min Gaade er et Guddoms-Ord, Som skaber hvad det nævner, Som fylder Dale trindt paa Jord Og Klipperne udjævner!

v. 11: Med Det indvier jeg min Daab, Velsigner jeg mit Bager,

Saa hist udspringer Livets Haab

Og her det vederkvæger!

Dette syn på Guds-Ordets gerning ved dåben og nadveren, som hører med til Grundtvigs "mageløse opdagelse" i 1825, måtte han senere på mange måder udbygge og især gennem en del "læredigte", hvoraf de fleste fra hans hånd kun foreligger i kladde, med ufuldført tegnsætning og ofte $\mathrm{i}$ et tungt sprog, så de er vanskelige af forstå og måske derfor i ringe grad udnyttet af Grundtvig-forskningen; men da de indeholder adskilligt, som kan tjene til at klare det stadig aktuelle spørgsmål om Guds ord og især det mindre væsentlige, men dog interessante: om Grundtvigs opfattelse af, hvad der er Guds ord, skal her fremdrages nogle af de vigtigste tanker derfra. Som noget af det forste må nævnes et digt, som oprindelig findes i SV I 81 med 42 vers: Gud taler, saa det sker - Det blev senere omarbejdet til Utrykte Psalmeblade 1843, GSV 3, 242, og igen 1853: Guds-Ordet, GSV 4, 396, med ny begyndelse:

Grund-Ordet er Guds Mund. Grund-Røsten er Guds Aande.

Som Munden gaar tilhaande

Og trøster i dens Vaande

Sin Ven af Hjertensgrund!

Det er nu ikke ved metafysiske spekulationer, vi skal finde ind til forståelse af Guds ord som Grundordet. Det er ganske lige- 
frem det, at ordet er grundled i hele skabelses- og frelseshistorien. Det er den handlende og virkende, fordi det er Guds Ånd der giver det røst og virkekraft. Dette skildrer da digtet i 51 vers, hvoraf her skal anføres v. 15 og v. 50 som prøver på, hvad Grundtvig kan sige om ordets magt:

\author{
Udsender Gud sin Aand \\ I Ordet: Guddoms-Blivet, \\ Da aabenbares Livet, \\ Men hvad os Gud har givet \\ Er altid i Hans Haand! \\ Hvem staar mod Ordets Gud! \\ Hvem kan da vel forhindre \\ Guds-Livet i vort Indre \\ Vort Støv at giennemtindre \\ Med Glands at bryde ud!
}

Her er ikke sat spørgsmålstegn, skønt sætningen er formet som et spørgsmål; men da det er klart, at ingen kan modstå Gud, slutter verset med et bedyrende udråbstegn, Grundtvigs ynd-. lingstegn. I sådanne vers bliver det fastslået både, at vi ikke har Guds ord i vor magt, og at han med ordet har magt over os, til liv og til vor frelse.

Det er en trossag, at ordet kan virke så store ting; men troen er underbygget med historiens vidnesbyrd gennem alle tider, fra skabelsens første dag til vore dage. Og hvorvel historien rummer megen usikkerhed, så giver den dog en solidere grund under troen end alle filosofiske spekulationer. Thi hvis man overhovedet kan kalde kristendommen en religion, da er den først og fremmest en historisk religion.

Dette syn kommer også stærkt frem i det store, delvis mytologiske digt på 216 vers fra 1860: Dansk Ravnegalder, hvoraf nogle vers efter forslag fra Carl Koch i Højskolebladet 13. 5. 1910 og med Laubs melodi er blevet til en kort og fyndig me'nighedssalme, se Den danske Salmebog nr. 236: Vanæret vor drot kom i sin grav -. I GSV 5, 125 er den optaget med lidt flere vers og indledes sådan: 
Guds-Ordet gik rundt, som Mand af Muld,

Og havde som Fugl ei Rede

Undtagen i Hjerter troe som Guld

Der vilde sig selv udbrede,

Men sagde han: gak! sprang Trold i Hav,

Og sagde han: kom! sprang Lig af Grav,

Ham alle Guds Engle tjende!

Grundtvig går ud fra, at vi kender de bibelske beretninger om Jesu kraftige gerninger, så han blot behøver at give en lille hentydning dertil, for at det kan stå os lysende for $\varnothing_{j e}$, hvordan Jesus med et Ord uddrev de onde ånder, så de med svinene styrtede i havet, Matth. 8,32, og hvordan han kaldte sin døde ven Lazarus frem af graven, Johs. 11,43.

Sådan besejrede han alle de onde kræfter, hvor han mødte dem på sin vej, og da han tilsyneladende selv var blevet besejret af den onde og nedfaret til Helvede, da vandt "Ordet " just sin største sejr ved hans opstandelse fra de døde:

Vanæret han kom vel i sin Grav, Skiøndt fint var hans Jorde-Lagen, Med Æren stod op, som Soel af Hav

Dog Ordet paa Tredje-Dagen,

Da runged det i Guds Engles Leir:

I Graven han vandt den største Seir, Udplyndrede Dødens Rige!

Og denne Ordets sejr over døden kommer os til gode derved, at det levende ord gør os levende ved dåben og skænker dette nye liv næring ved nadveren, hvor den opstandne frelser taler til hver enkelt af os, med ordet giver sig selv til os. Det beviser, at Gud nu som tilforn er med sin menighed, ganske vist usynlig for verdens øjne, men kendelig for den, der i tro modtager ordet.

v. 11: Det lille Guds-Ord, Guds Naades Bliv

Ved Badet og saa ved Bordet

Som skiænker til Troen Aand og Liv

Naar Hjertet omfavner Livs-Ordet

Beviser, at Guds eenbaarne Søn 
Hos Menighed sin er end i Løn, Skiøndt Verden ham seer slet ikke.

v. 12: Tre tusinde Sjæle paa en Dag

Blev levende af Guds-Ordet

Og sammen til eet Guds Vennelag

De smelted ved Himmel-Bordet

I Øst og i Vest, i Syd og Nord

Saa skabdes det Himmerig paa Jord

Hvor Christus er eet i Alle!

Mens Grundtvig i sine yngre dage mest talte om kirken, som dog for ham ikke var det ydre, tårnene, eller organisationen, kleresiet, men de "levende stene", så fandt han senere udtrykket "menigheden " mere rammende, eller som her et "vennelag " og i næste vers et "folk", jævne mennesker, men under de særlige kår, som Guds-Ordet skænker os:

v. 13: Saa fødtes det Folk en Pindsedag

Som aldrig skal Døden smage,

Hvis Fred ikke bryder Vaabenbrag,

Hvis Glæde ei Sorg kan tage

Hvis Ret er med Gud, hans Ord og Aand,

Hvis Haab sidder ved Guds Høirehaand,

Hvis Modersmaal er Guds-Ordet!

Vor opgave er alene at modtage ordet, som Gud taler til os. Det udtryktes i vers 1 ved, at hjerterne udbreder sig, og i v. 11 ved, at hjertet omfavner livsordet. Og når da Guds-Ordet er de kristnes modersmål og hjertesprog, der kommer fra hjerte og går til hjerte, da har det naturligvis bedre kår hos hjertefolket i Norden end noget andet sted og får et fristed hos os, fordi nødvendigvis friheden råder i hjertesager.

Sådan skildres det især i den sang om ordet, som Grundtvig gav overskriften "Ordets Kvoede», 5,161.

Hjerte-Tunger, som for Aanden gløde

Af den Ild, der fløi fra Himlen ned,

I, som Morgen-Solen purpurrøde,

Ægte farvet af Guds Kiærlighed! 
Hjerte- $\varnothing$ ren, kaldte frem af Støvet

Med et Effata: spring op og lyt

Til langt meer end Fugle-Sang i Løvet:

Til Hallelujaet, evig nyt!

Gud selv har givet ordet disse særlige organer, som er nødvendige for at det kan skabe og nære livet. Vore naturlige tunger og øren kan ikke klare sagen; de er alt for afhængige af vor fornuft, så først når de i stedet bliver underordnet hjertet, kan de tjene til ordets gerning. Det udredes nu i de følgende 31 vers, men kan vel kort udtrykkes sådan: Kun ord, der kommer fra hjerte og går til hjerte, kan levendegøre os og derved tillige bringe den sande og nødvendige oplysning:

\section{v. 5: Ordets Liv for alt hvad Folk har inde Lyset er imellem Mand og Mand Og end meer imellem Mand og Kvinde Soel og Maane er det trindt om Land!}

Også menneskeordet bringer liv og lys både i folkelivet gennem en folkelig vækkelse og i slægtslivet gennem den hjertelige forbindelse mellem mand og kvinde. Uden ordet kunne sandhedsånden ikke skabe folkeliv, og uden det ville forholdet mellem mand og kvinde synke ned til et rent kødeligt elskovsforhold:

v. 8: Uden Ordets Liv var Sandheds-Aanden

Overalt i Mandhjem stum og død,

Uden Ordets Liv var Liljevaanden, Hjertet, kun et kiælent Stykke Kiød!

Det er derfor en livsfjendsk tanke, man almindeligvis har givet Talleyrand æren for, at vi har făet ordet for at skjule vore tanker dermed; men Grundtvig kender ordet fra den engelske forfatter Edward Young: The Love of Fame. Derfor hedder det nu

v. 12: Ei ustraffet høres skal i Thule Lyden af den falske Vestenvind: Til at blotte ei, men til at skjule Tanker vore, skiødes Ordet ind. 
Sådan en sofisme må vi afvise ligesom påstanden om, at ordet ikke kan udtrykke, men kun betegne åndens liv - hvem det så end kan være, som har påstået det; v. 14. Så stiller Grundtvig sit syn op derimod:

v. 23: Herrens Røst ved Badet og ved Bordet

Den nu giøre vil det soleklart, At et evigt Liv der er i Ordet

Som fra Tungen det har Flugt og Fart!

Ved dåben og ved nadveren lyder Guds ord i sin kraft og skaber tro og håb, som det følgende vers siger.

Det er ikke alle ord, der har så stor en magt. Men selv hvor det som menneskeord er langt svagere, må det dog altid være den egentlige midler for oplivelsen og oplysningen. Det er som grundordet, subjektet, den handlende person og kan i pagt med ånden udrette store ting. Således siges det i 5,225:

v. 1: Ord om Aand i Støvets Mund Virkeligt i Støvets Øre

Det er Aande-Troens Grund

Ei at see, men dog at høre.

v. 2: Ord med Aand i Støvets Mund

Snart til Lyst og snart til Smerte,

Det er Hjerte-Troens Grund, Liv-Baand mellem Aand og Hjerte.

Der er en stigning fra "Ord om Aand" i v. 1 til "Ord med Aand " i v. 2, men ingen modsætning, ord om ånd kan og bør også være ord med ånd; og på samme måde er der en stigning men ingen modsæning mellem Aande-Troen og Hjerte- Troen, idet netop ordet opretter den levende forbindelse mellem ånd og hjerte. Disse to meget benyttede ord har hos Grundtvig en særlig betydning, idet ånd betegner det guddommelige indslag $\mathrm{i}$ menneskets tilværelse, og hjertet betegner det hos mennesket, hvormed vi modtager og formidler ånd, først og fremmest dens indslag i følelseslivet, der uden al sentimentalitet omfatter tro og håb og kærlighed. I stedet for det farlige udtryk "følelse" bruger Grundtvig gerne betegnelser som kraft og lys som udtryk for følelseslivets ytringer. 
v. 3: Ord om Liv i Støvets Mund

Som med Kraft vort Liv udtrykke,

Det er Ordets Klippegrund,

Prøvesteen for Skin og Skygge.

v. 4: Ord, som bælgmørkt eller lyst

Røber hvad vi har isinde,

Lampen er, hvorved i Bryst

Løgn og Sandhed let vi finde.

Den tankemæssige klarhed er ikke afgørende. Gud er klarest i det dunkle, og vi kan ikke med klare tanker og ord give èt fuldt udtryk for livet i vort hjerte; men ordet er lige fuldt den lampe, der hjælper os til at skelne mellem løgn og sandhed, mere gennem dets kraftige virkninger end gennem vore tanker derom.

Heller ikke ordet "rørelse" tager Grundtvig i den sædvanlige sentimentale betydning, men i dets grundbetydning af berøring og da især af Guds ord, så det ikke er noget, der stiger op af vort eget indre, men snarere noget, der strømmer ned over os, vækker røre i os og sætter noget i gang hos os:

v. 5: Ord, som Rørelsen giør stærk

For det Dybe og det Høie

Giør til største Underværk,

Hvad ei sees kan for Øie.

v. 6: Ord med Kraft og Mandevid

Straffer hver en Lyvetunge

Som af Barnet ret med Flid

Skabe vil en Skadeunge.

Det er netop modsætningen til sentimentaliteten, den uægte følelse, som vil give os skin af større fromhed end vi ejer, og som han her betegner med skældsordene Lyvetunge og Skadeunge, der jo ikke har noget at gøre med den uskadelige fugleunge, men betegner det uvorne barn, der skader ved sin uvederheftige tale, så det betegner en sladderhank og en vindhas.

Alt sådant uægte væsen skal Guds stærke ord få bugt med i det endelige opgør. 
v. 7: Herrens Ord, som har al Magt Skal naar Verden gaaer tilgrunde Med et Magtsprog, gjort som sagt, Stoppe alle Løgnens Munde.

Grundtvig var sig klart bevidst, at en sådan tale om ordets magt ikke var i overensstemmelse med verdens mening om den sag; men det skyldes, at verden kun kender ordet som det mere eller mindre fordærvede menneskeord, og ikke bryder sig om at kende Guds ord, fordi det kun elsker sit eget, og kun hvad man elsker kan man ret lære at kende. Det siger han i et digt fra 1867 , 5,329:

Hvad du ei elsker, det kan du ei kiende Som det i Aand og i Sandhed er kiendt Verden, som elsker til Tidernes Ende Ikkun sit eget, forbrudt og forvendt Den har for Aand og for Sandhed kun Kulde Kiender slet intet, som kiendes det skulde!

Trods sin egenkærlighed svigter den da også selverkendelsens strenge pligt, idet den på forhånd har afskrevet enhver forbindelse med den skabende kraft i Guds ord:

v. 2: Ikke sig selv, som ved Ord og ved Aande Skabt af den øverste, levende Gud, Kiende kan Verden i Vel eller Vaande, Thi kun af Mørke dens Lys springer ud Og i sit Hjerte den siger som Daaren: Død fødte Livet, som Vinteren Vaaren!

$\mathrm{Og}$ når verden ikke anerkender slægtskabet mellem Guds ord og menneskets ord, da synker dette ned til at være blot et mundsvejr eller en dyrisk lyd som fărenes brægen:

v. 3: Menneske-Ordet, den Tankernes Moder, Aandeligt Legem, usynligt for Støv Billed af Ordet, vor store Gud-Broder Hvori han blunder, som Barnet i Svøb, Det kalder Verden et Mundsveir som Bræget Avlet af Stumhed og borget fra Kvæget! 
Det er sjældent, Grundtvig skriver et helt digt så negativt som disse tre vers; der følger gerne et positivt modstykke; og der er god grund til - som Sv. Grundtvig og Kr. Madsen - at antage, at dette digt fortsættes $i$ et andet med samme emne og samme versmål, kun i v. 1 lidt udvidet, selv om de to manuskriptblade er skilt. Ved en nøjere undersøgelse ser man da også, at de to blade passer sammen i brudfladen, så de godt kan være revet fra hinanden. Begge er af Grundtvig mærket med årstallet 1865, så de er i hvert fald fra samme tid. Det andet stykke har fået nr. 5,331:
Vel dig, Guds-Menneske, vaagnet af Dvale
Vaagnet ved Røsten: hvor, Adam, er du,
Med Eva, den Skiønne, fra Edens Løvsale
Med Jord under Fode, med Himlen i $\mathrm{Hu}$,
Med Ordet paa Læben, som skal det stadfæste:
Med Gud kan du tale som Mand med sin Næste!

Det er det nødvendige modstykke til den før skildrede verden, Guds-Mennesket, som vedkender sig sit slægtskab med Gud, netop ved ordet som meddelelsesmiddel og bindeled. Og Grundtvig glemmer ikke, at dette Guds-Menneske, som elsker ordet, skal da også lære alt det at kende, som verden ikke kender:
v. 4: Derfor, Guds-Menneske, alt du skal kiende Som hører Aanden og Sandheden til, Tidernes Fylde og Tidernes Ende
Klart skal du skue i Soelglandsen mild Som det Guds-Ordet har skabt og udtrykker Menneske-Ordet med Glæde samtykker

Det er et udmærket udtryk for samspillet mellem Guds og menneskers ord, at Guds ord er det skabende og rådende, mens vort ord må være samtykkende, et ja til Guds ord, til Jesus Kristus, som har udvalgt os til sine tjenere og gør os til brugelige redskaber ved at danne vore hjerter og klare vort syn for sandheden.

v. 5: Christus, vor Jesus, Gud-Faders Eenbaarne!

Du er Guds-Ordet, Guds-Aanden er din, Børne-Ret fik vi som dine Udkaarne 


\section{Aand du os skiænker som Himmerigs Vin, Hjertet du danner og Synet du klarer Sandheden selv i dit Ord aabenbarer.}

Og Grundtvig kan ikke slutte denne menighedens bekendelse til ordet - som modstykke til verdens dom derover - uden at nævne dåben som det sted, hvor Jesu "lærdom " forkyndes os, og nadveren som det sted, hvor hans liv skænkes os. Og han giver også Kristus æren for både den himmelske og den jordiske lovsang af Guds ord, ham som er selve grundordet, der åbenbarer os Guds visdom:

v. 6: Det er din Lærdom, som lyder ved Badet, Det er dit Liv, som er Mad paa dit Bord Det er din Sang, som Guds Engle fra Bladet Spille paa Harper til Pris for Guds Ord, Det er dit Ord til Guds Lærlinger alle, Som alle Himle Guds Viisdom maae kalde!

\section{Livs-Ordet}

Ordets vigtigste opgave er at bringe liv fra Gud til mennesker, og derfor kalder Grundtvig det ofte livets ord. Og det er ikke blot kristenlivet, som det skænkes os ved dåbens ord, som hæver vor sjæl over naturens plan med dets højdepunkt i ørnens flugt, 5,292 :

Hvad er det, som vore Sjæle

Hæver over Ørnens Flugt?

Det er Aandens Mund og Mæle,

Det er Hjertedybets Røst; Høitids-Ordet, lavt og lydt, Gammeldags og nytaarsnyt, Om det Dybe og det Høie, Som er dulgt for Verdens Øie.

Højtidsordet er ikke blot de stærke evangelietekster, vi hører på kirkens højtidsdag, da det lyder særlig klart, men også alle de andre kirkeord, som nok er gamle, men dog altid nye, når de 
åbenbarer os det dybe og høje i tilværelsen, som verden ikke ser og kender.

$\mathrm{Og}$ gælder det menneskelivet, så gælder det i endnu højere grad kristenlivet, at det skænkes os ved ordet:

\author{
Hvad er det, som vore Sjæle \\ Skænker Lys og Liv og Fred? \\ Det er Himlens Mund og Mæle, \\ Guds det evige Livs-Ord, \\ Jesu Christi Røst og Navn \\ I hans fjerne Fødestavn, \\ Og saa vidt, som i Lovsangen \\ Lever, lyder Efterklangen.
}

Det var ikke blot den gang, i tidens fylde, og der langt borte, i Palæstina, at det evige livs ord lød med Jesu røst, men det lyder også her og nu. Det var vel at vente, at Grundtvig som præst ville have nævnt prædikenen som genlyd af evangeliet, for det burde den være og var det også i langt højere grad i 1864, da han skrev denne salme, end i 1810, da han holdt sin dimispræediken over det tema: "Hvi er Herrens Ord forsvundet af hans Hus?" Men her næuner han nu lovsangen som den levende genklang af evangeliet, måske fordi han havde erfaret, at hans salmer gengav det levende ord bedre end hans prædikener. Men endnu bedre møder vi livsordet ved dåben og nadveren:

v. 3: Hvor er det, vi Ordet møde, Som er baade Aand og Liv, Jesu Aand med Liv af Døde, Naade-Strømmens Kildevæld?

Det er paa den hele Jord

Kun ved Jesu Bad og Bord:

Aande-Badet og Guds-Bordet, Aand og Liv er der Guds-Ordet!

Ofte udtrykker Grundtvig sin fulde forvisning og store glæde over de glimt fra den evige og usynlige verden, som møder ham, ved at sige: kun der findes det! Det er ikke et nedsættende ord, heller ikke altid et afgrænsende ord. Vi er helt udenfor 
sammenhængen, hvis vi her begynder en sofistisk debat om berettigelsen af dette "kun". Det kunne aldrig falde Grundtvig ind at begrænse ordets virkefelt til dåb og nadver. Han nægtede ik$\mathrm{ke}$, at det kunne lyde $\mathrm{i}$ en salme eller en prædiken, men der ville den menneskelige medvirken altid gøre sig gældende, men det er i den grad noget sekundært, at vi må sige: Kun ved Jesu Bad og Bord - møder vi ordet som et ord til os.

"Det evige Livs-Ord" er overskriften på et digt fra 1855-56, hvori digteren lader vor Herre selv føre ordet, 5,67:

Vender du, som jeg har kaldt

Brud og Menighed udvalgt

Rygg til Sandheds Avindsmand,

Drot i Dødens mørke Land,

Knæl da her i Engle-Hegn

Under Korsets Himmel-Tegn!

Fra den mageløse opdagelse i 1825 af dåbspagtens ord som det xgte og oprindelige udtryk for sand kristendom holdt Grundtvig gang på gang - også $\mathrm{i}$ sine salmer - forsagelsens og troens ord frem som det vigtigste ord for os kristne. Ved dåbshandlingen fastholdt han det uændret i protest mod dem, der ville modificere liturgien ved at afsvække de gamle udtryk; men i salmerne kan ordene meget vel frit omskrives, og således er det første vers her en omskrivning af forsagelsen. På tilsvarende måde gengives trosbekendelsen frit i de følgende vers, og derpå hedder det:

v. 5: Lægger du, som Hjertet vil Ja og Amen dit dertil $\mathrm{Da} \mathrm{i}$ Vand med Ord og Aand Bader dig min højre Haand Og til Skjønhed over Sky

Fødes du deraf paany

Det er Herrens brud, den kristne menighed, hvis skønhed alene kommer af, at han "rensede den i vandbadet med et ord ". Og skønheden beskrives med de ædleste blomsters navne, og næsten i stil med Højsangen hedder det 
v. 9: Jeg er din og du er min, Fælles Himlens Brød og Viin, Aandens Kraft og Hjertets Fryd Bryllups-Sangens Fløitelyd, Kiærlighedens Hvile sød, Evigt Liv i Lykkens Skiød!

Men det siges klarere her end i Højsangen, at denne søde forening og høje lyksalighed ene skyldes Guds ord, modtaget i tro:

v. 10: Det er Summen af Guds Ord

Ved Vorherres Bad og Bord,

Ordet i Vorherres Navn

Tager Troen ømt i Favn,

Som en Seier-Frue bold

Med Guds-Ord til Soel og Skjold.

At Guds ord og vor tro hører sammen, er da klart nok. Men hvordan kan vi nu vide, at den tro, vi bekender, er den rette og sande, den evigt virkende og frelsende? Dette vigtige spørgsmål besvares i 5,239: Livs-Ordet til os af Jesu Mund.

Udfrittes du, hvoraf vi veed,

At Troen, vi bekiende,

Gaaer med Guds Folk og Menighed

Fra Øst til Verdens Ende,

Saa Troens Ord af Jesu Mund

Er Hjørnestenen allenstund

Paa Jorden for Guds-Huset.

Svar aabenlydt: hvad Gud kun veed,

Kan for sig selv bevise,

Det er, hvor Engle op og ned

End stige, Gud at prise

For Jesus hans eenbaarne Søn,

Som var i Lys og er i Løn

Paa Jorderig Guds-Ordet!

Spørgsmaalet er vel i sig selv lige så indviklet som Grundtvigs sætningsbygning her, især hvis de to vers adskilles ved et punk- 
tum, for da er det svært at se, at hele første vers er en bisætning: hvis du udfrittes - så kommer hovedsætningen i det andet vers, hvis mening må være, at vi skal svare på det spørgsmål: at det er noget, kun Gud kan vide, og han bor i sin himmel, men har ladt sit ord blive kød og tage bolig iblandt os, Jesus Kristus.

Og hans røst tør vi godt tro, selv om meget i de gamle beretninger er dunkelt såvel som det, der siges om det kommende.

v. 3: Hvad fordum sig paa Jord tildrog,

Og hvad herefter kommer,

Med ham, som sig vort Kiød paatog,

Vor Frelser og vor Dommer,

Er ei saa grant, som To er To,

Men godt vi tør Guds-Røsten troe,

Som vækker op afdøde!

Sædvanligt siger man: "Det er så klart som to og to er fire!" Men Grundtvigs formulering er endnu enklere og klarere: at to er to. $\mathrm{Og}$ lige så indlysende er det, at vi tør tro Guds røst, når den kalder os til live, og især indlysende ved dåb og nadver, hvor han selv taler til os på to mands hånd.

Vi troe, Guds Rige kom os nær

Med Badet og med Bordet,

Og Hjertet følde dybt, at her

Tiltaler os Livs-Ordet:

Omvender jer og giver Rum

Guds Riges Evangelium!

Da til Guds Folk I fødes.

Det er vor Herre selv, som taler sit levendegørende ord til os, og af dets virkning kan vi kende dets sandhed. Et kraftbevis er bedre end en logisk slutning, erfaringen giver en større vished:

v. 10: Saa vist som Jesu Tro og Daab

Da findes under Solen,

$\mathrm{Og}$ føder et livsaligt $\mathrm{Haab}$

Om Liv fra Naade-Stolen,

Da lyder end hos os paa Jord

Det Pagtens, Troens, Daabens Ord,

Som Jesu Mund udtalde. 
Dansk Kirketidende, hvori dette digt første gang blev trykt, den 25.10.1863, har her en trykfejl, som er gået igen i alle senere tryk, så verset begynder "Saa vidt", og det kan også give en skikkelig mening; men de tre bevarede håndskrifter har alle "Saa vist", og det drejer sig netop her om at fastslå visheden, sikkerheden for, at dåbens ord er vor Herres og derfor urokkeligt og livsaligt. Og det mærkelige er, at denne sikkerhed knytter Grundtvig ikke til bibelordet Ap. G. 1,3 om, at Jesus i de 40 dage mellem hans opstandelse og himmelfart talte med sine disciple om de ting, der hører Guds rige til, men han knytter det til det talte og hørte ord i menigheden nu, det levende ord. Denne tanke udvikler han nærmere i 5,229: Livets Ord
Ønsker, Lille! du at leve,
Længe leve sjæleglad,
Stol da ei paa Himmelbreve!
Livets Bog har Tungeblad.
Stol kun paa et stærkt Guds-Ord,
Som du horde, som du troer!

Bibelen kalder han et brev fra himlen, så han vurderer den såre højt, men den er dog ikke livets bog, som må have levende tunger i stedet for døde blade, så vi kan høre og tro, ikke se og vide.

$\mathrm{Og}$ da vort liv ikke er vor ejendom, men et lån af Guds skaberånd, afhænger det bestandigt af Guds ord, som vi lever med og af:
v. 2: Laan er kun dit Liv igrunden,
Er din Skabers Aandepust,
Med Guds-Ordet af Guds-Munden
Aander vi og lever just,
Timelig med Ordet tyst,
Evig af det aabenlyst!

Her i tiden er vort samliv med Guds ord meget stilfærdigt, tyst er dog ikke stumt, men i evigheden skal vort liv ud af ordet blive helt åbenbart. Og som livet selv er ældgammelt og dog bestandig nyt, sådan må også det ord, som holder os i live, være fra Arilds tid, men lyder nu til os af Jesu mund, hvoraf skriften kun er en skygge: 
v. 3: Livets Ord, hvorpaa du bygger,

Gammelt være maa og nyt,

Som af Mund ei blot af Skygger

Til dig tales aabenlydt,

Tales dog, som det kom hid,

Som det lød fra Arildstid.

Når til dig er understreget - og i næste vers han til os - er det for at fremhæue den personlige forbindelse mellem Gud og os, som virkeliggøres ved hans ord til den enkelte ved dåb og nadver:

\title{
v. 4: Christus kun, som selv er Livet, Livets Ord har i sin Magt, Aand og Liv er os kun givet I hvad han til os har sagt, Siger ved sit Bad og Bord, Som det levende Guds-Ord!
}

Derefter minder Grundtvig os om, at den apostolske trosbekendelse er det eneste ord, som fra gammel tid er kaldt troens ord, og når vi tilegner os det ved dåben, da er vi Guds børn og må nyde barnekårene alt som vi beder barnebønnen, trods al vor brøst og synd:

\author{
v. 9: Da Guds Aand dit Haab beseigler \\ I Vorherres Jesi Navn: \\ Et Guds Barn, ihvad dig feiler, \\ Du er da i Christi Favn, \\ Nyder Herrens Barnekaar, \\ Som du beder "Fadervor! "
}

Og som slutstenen på denne lovprisning af livets ord står et vers om nadveren, hvor det er ordet, eet med Jesus selv, der spises og drikkes under brødets og vinens skikkelse, så vi derved forenes med vor Herre til det evige livs samfund:

Nadver-Ordet, naar det ædes

Drikkes ret ved Herrens Bord, Hvor du færdes, hvor du stædes, 
Er det levende Guds-Ord, Herren, som indbyder dig

Til at leve høit med sig!

\section{Kirke-Ordet}

For Grundtvig var Guds ord på det nøjeste forbundet med menighedslivet, som det normalt udfolder sig i kirken. De gudelige forsamlinger var ikke rigtig efter hans sind, selv om han nok kunne anerkende de troendes trang til at samles om ordet, selv i den usleste hytte og da især, hvis der i kirken kun lød rationalistisk tale, måske tilmed forvanskede ritualer og udvandede salmer til dødbidermusik.

Men ellers priste han kirken, ikke blot den af levende stene, men også husene med kirkenavn. Og han vil derfor gerne kalde os til kirke som i et digt fra 1857, som nu har fået plads i vor salmebog og har vundet anerkendelse især som dåbssalme, skønt den også taler om bøn og i et vers, der ikke kom med i salmebogen, om nadveren. Det er 5,108:

Op til Guds Huus vi gaae
Og banke dristig paa:
"Luk op», det er vor Bøn!
Vi leder om Guds Søn.

Som Lynild farer brat, Os Døren er opladt, I Daab med Aand og Vand, Her staaer vor Frelsermand.

Ved dåben indføres vi i Guds menighed, den er døren til Guds rige, som lukkes op for os ved Guds hånd, ligesom vor sjæl lukkes op for hans ord ved hans underfulde indgriben, når han taler sit Effata til os som til den døve, Mark. 7,34:

v. 3: Vor Sjæl er døv og stum For Evangelium, Men høres vil Guds Ord Og føres trindt paa Jord. 
Denne Guds indgriben sker ved dåben, hvor Gud med sit spørgsmål til os, om vi forsager Djævelen og tror Guds sandhed, baner vej for ordet, så det også kan lyde til os og fra os i barnebønnen, Fadervor. $\mathrm{Og}$ ved nadveren indelsker han $\mathrm{i}$ os det rette barnesind:

\section{v. 10: I Jesu Christi Navn Han tager os i Favn, Og kysser $i$ os ind Et himmelsk Barnesind.}

Guds kys er hos Grundtvig en betegnelsen for nadveren, se allerede Nytårsmorgen v. 43: Han skjænked mig Livet, Som Ham det er givet, Med Kysset i Kjærligheds Kalk!

Og de mange steder i salmerne, hvor kysset nævnes, er det altid faderens kys til sit barn, aldrig elskerens kys til sin brud.

Denne faderkærlighed møder os også i den bøn, han ved sin søn har givet os, Fadervor, der hører med til kirkeordet, selv om nogle af os har haft den lykke at lære det i barnekammeret. Den er dog immer vor Herres bøn, før den bliver vor, og han har givet den til kirken, til vor moder. Herom hedder det $i$ et digt fra 1862, 5,175:

Fadervor er Herrens Bøn,

Givet til vor Moder,

Kiærlig stilet af Gud-Søn,

Som vor ældste Broder,

Saa med Sønnen bedes kun

Fadervor af Hjertensgrund,

Med hans Aand tillige!

Den kaldes i næste vers faddergaven til os ved dåben, og det er $\mathbf{i}$ kraft af de børnekår, der gives os $\mathrm{i}$ dåben, at vi kan bede den. Ellers vil den kun være tomme ord:

v. 3: Lases kan hvad skrevet staaer,

Staves alle Bønner,

Bede kan dog Fadervor 
Døttre kun og Sønner, Staaende paa Barnefod Med Gud-Fader eiegod, Bede, saa det baader!

Blandt de stærke kirkeord fremhæver Grundtvig også den aronitiske velsignelse, det ældste led i hele vor liturgi, arv fra den jødiske menigheds første dage, men først fuldbyrdet i Kristus og ved ham gået $i$ arv til os og blevet til en menighedshandling. Om den hedder det i 5,176, Velsignelsen:

\author{
Velsignelse, al Jordens Tarv, \\ Velsignelsen er vores Arv, \\ Velsignelsen af Himlens Gud \\ Er Vinen i hans Giæstebud! \\ Velsignelsen af Gud tilsagt \\ Var Perlen i den gamle Pagt, \\ Men kun med "Saden" som Guds Ord \\ Velsignelsen fik Hjem paa Jord.
}

Det korte bibelcitat "Sæden " har forbindelse til flere steder, først til Guds forjættelse til Eva: Kvindens sæd skal knuse slangens hoved, 1. Mos. 3,15, dernæst til Abraham: I din sæd skal alle jordens folk velsignes, 1. Mos. 18,18, hvad Paulus igen udlægger om Kristus i Gal. 3,16. Og i Kristus virkeliggøres det på den måde, at han sår ordets sæd i menneskehjerter, Luk. 8,11. Og denne sæd kommer da til enhver af os ved dåben og nadveren:

\author{
v. 3: Velsignelsen som Dugg og Regn \\ $\mathrm{Nu}$ falder i hver Himmelegn, \\ Guds Menighed tilbudt, tillagt \\ Ved Pagten ny, ved Daabens Pagt! \\ Velsignelsen i Herrens Stad \\ Giør Daaben til et himmelsk Bad, \\ Giør Nadveren som Herrens Bord \\ Til Hjertets Himmerig paa Jord!
}


Velsignelsens kraft er ikke udelukkende knyttet til de kendte ord fra 4. Mos. 6,24-26: Herren velsigne dig og bevare dig! Herren lade sit ansigt lyse over dig og være dig nådig! Herren løfte sit åsyn på dig og give dig fred!

Men den samme åndelige kraft, som er i disse gamle ord, møder vi også i dåbs- og nadverordene som udtryk for Guds velsignende nåde.

Hvordan iøvrigt kirkens gamle ord skal lyde på de skiftende tiders sprog, kan det være svært nok at finde ud af. Det er i vor tid såvel som i Grundtvigs en ofte fremført indvending mod kirken, at den taler et sprog, som er uforståeligt for nutidsmennesker.

Men sproget skal naturligvis være tjener og redskab for ordet, det ældgamle og særprægede; derfor må det også have sit særpræg, der dog godt kan være så jævnt og enfoldigt, at det kan finde vej til nutidsmennesker i hverdagen. Derom hedder det $\mathrm{i}$ 5,134:
Kirke-Ordet og Kirke-Sproget
Godt kan enes i Aandens Mund,
Er end meget i Kirken broget,
Klar er Kilden i allen Stund,
Det er Mesterens Himmel-Tale
Ild og Lys under Bølger svale!

Jesu ord er klare nok og fyldt med varme og lys, som de stadig kan bringe til alle folk, selv om ånden i dem kun flammer skjult og livet bor lønligt i dem under de skiftende tiders forkyndelse, så den ikke bliver uden frugt:

v. 2: Saa hos Folket af alle Stammer

Liv og Lys er de "gamle Ord"

I dem Aanden forborgen flammer

I dem Livet forblommet boer, Med dem stiger og daler Røsten, Grønnes Vaaren og gulner Høsten!

Det havde Grundtvig opdaget gennem sine undersøgelser af kirkens historie hos de forskellige folkeslag, at i samme grad som 
de gamle ord fik lov at gøre sig gældende, styrkedes forkyndelsen og derved menighedslivet. Det var ikke mængden af "Gamle ord “ det kom an på, men styrken i de fă, først og fremmest ved dåben og nadveren:

\section{v. 3: Kirke-Sprogets forborgne Kilde, Christus-Folkets de gamle Ord, Faa i Tallet som Herren vilde, Hører du ved hans Bad og Bord, Der er Aanden og der er Livet Laant til Tungen og Hjertet givet!}

Den, der fremfører disse ord, kan ikke herske over dem, men får dem kun som lån, mens den, der hører dem, făr dem som gave til evigt eje, dog ikke som en død skat, thi Guds ord er virksomt, giver ikke blot hvile $\mathrm{i}$ troen, men fremgang $\mathrm{i}$ håbet og handling i kærligheden:

\section{v. 4: Troen hviler og Haabet stiger, Kiærligheden giør hvad den vil, Livet dages og Døden viger, Lyset tændes ved Himlens Ild Ordets Væld som ei Tungen tømmer Ud da springer, og Talen strømmer!}

Det er den gamle præsts lykkelige erfaring, at hvor mange prædikener han end har holdt over hvert af de gamle ord, kan hans tunge dog aldrig udtømme ordets væld, den levende kilde, som făr vor tale til at strømme, som andres tale ned gennem tiden har gjort det, ofte vel brudt og blandet med jordens slam, men dog altid med et klart kald til Paradis:

v. 5: Talen strømmed til os fra Østen Brudt og blandet paa sælsom Viis Kildet-Ordet med Himmel-Røsten Dog os kalder til Paradis Findes Dybet i Hjertets Dale Da gienfødes den rene Tale! 
Det er den korte og klare regel, hele Grundtvigs homiletik, at hvis Guds Ord går til dybderne i vort hjerte, da genfødes det på vore læber som den rene tale, det sande og derfor stærke vidnesbyrd. Da kommer der også liv i skriftens ellers døde ord, når sandhedsånden får lov at fremføre dem:

\section{v. 6: Runer ristet af Mester-Hænder}

Viser Løbets det gamle Spor,

Sandheds-Aanden, som alting kiender,

Sjælen er i de "gamle Ord"

Yndig strømmer, hvor han mon raade,

Sandhed sammen med Liv og Naade!

Og deri gives da et tiltrængt og godt korrektiv til den ofte noget kategoriske tale om bibelens døde bogstaver, som har givet Grundtvig navn af bibelforagter, skønt han netop fra sin ungdom af, nærmere betegnet fra Langelands-tiden, var lidenskabelig og tænksom bibelgransker.

\section{Skrift-Ordet}

"Runer, ristet af Mesterhænder" - det er en betegnelse for bibelen som tillige med mange andre klart viser Grundtvigs høje tanker om bibelen. Den er et menneskeligt mesterværk, uundværlig for kristne, men utilstrækkelig til at vække liv og tro. Derom havde Grundtvig i 1856 skrevet et digt, 5,18: Bibelen og Christendommen.

Bogen over Bøger alle,

Bøger med Støv-Fingre gjort

Rune-Skrift af Mester-Skjalde

Som stod Vagt ved Himlens Port

Forudsaae, hvad vore Sjæle

Lede om og pønse paa,

Og gav ham sit Eftermæle

For hvis Domstol vi skal staae!

At bibelen er skrevet af menneskehænder, stiller den på linje med de øvrige dunkle og skønne skrifter fra gammel tid, så det er kun dens indhold, der sikrer den førstepladsen i al litteratur, 
dels det gamle testamente med forjættelserne, som imødekom vor trang og vore forhåbninger, dels det nye testamente med Jesu eftermæle, evangeliet om hans ord og gerninger. Den er derfor et underværk, at ligne ved et stort træ, opvokset af ordets lille frø. Bibelen er derved blevet et hjemsted for himlens fugle, Guds ord, så den kan ikke prises for højt, når det kun ikke sker på åndens bekostning, så den sigtes for at have stjålet ordet fra bogen:

v. 2: Om det Underværk paa Blade, Gaadefuldt som Løv i Lund, Hvor sig Himlens Fugle glade Rede giør i allen Stund, Ingen Skjald for høit kan sjunge, Ingen Tanke er for dyb

Naar kun med sin Glød paa Tunge Aand ei sigtes som en Tyv!

En sådan sigtelse mod Gud Helligånd, at han hentede al sin tale ud af skriften, havde Grundtvig bl.a. fundet i H.N.Clausens bog om katolicismen og protestantismen, der straks efter sin fremkomst i 1825 blev mødt af Grundtvigs voldsomme modsigelse: Kirkens Gienmæle; men det var stadig - og er vel endnu - nødvendigt at kæmpe mod denne vildfarelse. Det ville være galt nok, om man beskyldte lærken og nattergalen for at have "stjålet " deres sang, men det er dog langt værre at beskylde ånden for at hente sit liv og sin tale fra den dunkle beskrivelse i bibelen:
v. 3: Men om Lærken i det Høje,
Nattergalen lavt paa Kvist
Maatte det af Daaren døje
Ingenting det var dog vist,
Mod den Uret, Aand maa lide,
Som sit Liv, sin Røst og Sang
Han kun fandt ved Nattetide
I sin egen Løndoms-Gang!

"Som" i linje 6 betyder "Som om" og betegner modpartens beskyldning - at ånden kun fandt sit liv og sin tale ved natlige 
studier i bibelens dunkle gange. I modsætning til denne opfattelse prises da åndens storhed $\mathrm{i}$ de næste vers, og på denne baggrund må vi se bedømmelsen af skriften som en dom over skriftforgudelsen: at sætte skriftkundskaben i stedet for åndens levendegørende virken.

v. 7: Ingen Bog sig selv kan skrive,

Mon sig selv den kan forstaae?

Kan hvad ei er selv ilive

Liv at skiænke selv formaae?

Eller kan nu Skolepoge,

Som ei Glimt af Aand har mødt,

Meer end Israels Skriftkloge,

Blæse evigt Liv i Dødt?

De skriftkloge jøder var jo blandt Jesu hårdeste modstandere, fordi de læste skriften uden åndens vejledning, kun udfra deres egen forstand og de gamles overlevering. Derfor kunne de ikke se, at skriften viste hen til Jesus som den kommende Messias, Johs. 5,39 og f. Og hvad Jesus sagde til dem, må hans ånd nu sige til os, v. 12, og i v. 14 henvises til endnu et skriftord, 1. Joh. 4,2:

\author{
Har I ikke læst i Skriften, \\ Hvad dog klarlig skrevet staaer, \\ At den Aand, som Livs-Bedriften \\ $\varnothing$ ver alle Herrens Aar, \\ Sandheds Aand, som han udsender \\ Folk til Trøst i Liv og Død \\ Er den Aand, som lydt bekiender \\ Christus, som han kom i Kiød?
}

Sådan bekender den kristne menighed under åndens vejledning just ved dåben sin tro på Jesus Kristus, vor Herre, som er undfanget ved den Helligånd og født af jomfru Maria. Denne tro og bekendelse er den klippe, Kristus har bygget sin kirke på, Matth. 16,18. 
v. 19: Troens Ord ved Christen-Daaben

I Guds-Menighedens Mund, Ved Bekiendelsen holdt aaben

Af Guds Aand i allen Stund, Det er Klippen, det er Fjeldet Som Guds-Huset hviler paa, Og deraf udspringer Vældet: Livets Flod i Draaber smaa.

At der udvortes set kun er nogle få dråber vand, der bruges ved dåben, hindrer ikke, at den åndeligt er livets flod, troslivets kilde, ligesom de få ord, der tales ved dåben, kan føre os ind i alt det værdifulde, skriften gemmer.

v. 22: For den Røst sig skal oplade

Aandens Giemmer trindt paa Jord

Med den Grav af Palme-Blade

Hvori skrinlagt er Guds Ord,

Til Opstandelse begravet

Dvaledødt med Englevagt,

Det staaer op som Soel af Havet

Glimrende i Straaledragt!

Selv om skriften er død, så er dog Guds ord, som er begravet deri, kun dvaledødt og kan opstå, når Gud vil det. Sådan havde Grundtvig selv i sin ungdom oplevet det under, at ordet blev levende, og gennem sin livslange præstegerning oplevede han det gang på gang. Men det var Guds ånd alene, som vakte det til live.

Det er ved åndens røst, ordet kan kaldes til live her og nu. Og det er da også denne røst, der med dommedagsbasunens stærke lyd skal vække os op af døde på den yderste dag, for at vi kan fare til vor frelser med glæde.

v. 23: Dermed varsle Herrens Døde, Som staaer op ved Aandens Røst

Om den store Morgenrøde Meer end Vaarens skiøn i Høst, 
Da den hele Helgen-Skare

Vaagnet under Lures Brag,

Skal til Frelseren opfare

Og lovsynge Dommedag!

Og det lange digt slutter med, at domsbasunen vil kundgøre "Guds-Ordets Magt", da dets gerning så er fuldført til sejr.

\section{Den levende Røst}

Grundtvig skrev adskillige lange digte, som tillige var så vanskelige at forstå, at en stor del af dem stadig er uopdyrket steppe eller jungle. Det gælder således det mærkelige digt Havamal fra 1866 (Poet. Skr. IX s. 293-499) med 1060 sekslinjede strofer, hvoraf mange taler om ordet og dets betydning, navnlig fra $\mathrm{v}$. 220 (s.339) i et afsnit med overskriften "Ordet, Tiden og Levnedsløbet ".

Det begynder sådan:

I Begyndelsen var Ordet,

Evig født af Gud til Gud,

Var med Almagts-Kraft omgjordet,

Gik med Liv i Røsten ud;

Da med Røsten og dens Kræfter

Skabdes Tiden, for og efter.

I den gamle bibeloversættelse, som Grundtvig altid brugte, står der i 1. Mos. 3,8: "Og de hørde Guds HERRENS røst, der gik i haven, der dagen var luftig ". Denne røst har gennemtonet hele menneskeslægtens historie fra skabelsens morgen, har præget enhver tid og formet hele slægtens liv ved de ord, Gud har talt. Det er røsten, der gør ordet levende og virksomt. De fleste af de følgende 800 vers handler da om ordets historie, om dets gerning og virkning.

Det længste digt, som er taget med i Grundtvigs Sang-Værk, er fra 1863 og har 248 vers, der næsten alle handler om dette ene ganske vist omfattende emne, som Havamal har 800 vers om: Røsten, der bærer Guds ord og gør det levende og virksomt hos os. 
Førstetrykket af Den levende Røst uddeltes af Grundtvig ved vennemødet i København 9. og 10. september. Det har ligesom 2. udg. fra december samme år som undertitel: "Minde-Blade fra Venne-Mødet i Septemberdagene«. Det kunne da også minde deltagerne i mødet om Grundtvigs tale på mødets første dag, der som hovedemne havde en påvisning af, at ikke skriften, men kun det levende ord kunne vække åndeligt liv hos mennesker.

Digtet må dog være udarbejdet, før talen blev holdt; det har i hvert fald vist sig, at der findes et meget stort forarbejde i manuskript, som må have stået på i adskillige uger.

Her skal blot gives et par prøver fra dette digt, idet jeg kan henvise interesserede til en mere udførlig gennemgang af digtet, som jeg har givet i Grundtvig-Studier 1958, s. 36-46.

Der er endnu flere fremhæuelser $i$ dette digt end i de fleste af Grundtvigs, og det tyder på, at det er skrevet i en særlig opstemt periode. Det begynder sådan 5,233:

Lovsunget blev Røsten

Af Aanden i Østen

Paa Tungen især;

I Nord paa det jæune

Med Horelsens Evne

Den Hjertet blev kiær!

I jødefolkets beretning om Guds skabergerning, slægtens opdragelse og forjættelserne om en frelser finder Grundtvig nu denne lovsang til røsten som et udtryk for ånd.

Den, der fremfor nogen har prist røsten, er kong David, hvis salmer var det levende forbillede for Grundtvigs egen salmedigtning, og her må vi særlig fremhæve salme 29, hvor der står, at Herrens røst var over vandene med kraft og herlighed.

Denne røst blev især hørt i Norden, hvor vi havde sans for hjertets tarv og derfor hørte hjerteklangen i Guds røst:

v. 5: Hvad Øret ei hører, Det Hjertet ei rører

Til Lyst eller Nød, Saa synger Heltinden

Med Taare paa Kinden, Glands-Taaren guldrød! 
Denne heltinde er ifølge det næste vers kærlighedens gudinde her i Nord, Freja, og hvor hun så end kan have fået det gamle mundheld fra, så bliver det i hvert fald stadfæestet af Jesus, bl.a. i Matth. 13,43: Den, som har øren, han høre!

\section{v. 8: Det Mundheld stadfæster \\ Vor himmelske Mester, Guds-Munden på Jord: \\ Enhver, som har Øre, Han mærke, han hore \\ Guds levende Ord!}

Det emne behandles da på mange måder hele digtet igennem. Og især fremhæves det, at Jesus selv ikke skrev en lærebog til sine disciple, men lagde dem sit ord i munden og sin ånd i hjertet:

v. 126: Guds-Husets Stormester

En Haandbog for Præster

Ei risted med Stav,

Men lagde Livsgrunden,

Sit Ord dem i Munden,

Dem Røst dertil gav,

Ei vilde han Penne

Fra Himlen dem sende,

Men Tungerne ny,

Som Ildens saa røde,

Som hans til at gløde

Med Ord-Blus i Sky!

Og som disciplene på pinsedagen fik ånden og ordet skænket, vil Guds ånd fortsætte denne gerning i den kristne menighed hos alle folk og til alle tider, så frelserværket derved kan krones med held. Derfor kan sangen slutte med et fortrøstningsfuldt fremblik som i sin tid Nyaars-Morgen. Her hedder det, v. 248:

Lyd høit over Vangen, Med Hjertedybs-Sangen,

Guds levende Rost; 
Saa Verden maa sande,
Du skaber om Lande
De Levendes L $y$ st!

Hovedtankerne i dette lange digt blev sammentrængt $i$ et digt på "kun" 42 vers $i$ et lidt ændret versmål, 5,234, og det blev igen $\mathrm{i}$ det følgende år forkortet til en salme på 9 vers og optaget i Fest-Psalmer, 8. oplag, nr. 909:

\section{Hører du Røsten, Raabet fra Østen, Hvor Solen opstaaer, Og i Lovsangen Hjerte-Gienklangen Til seent Gyldenaar!}

Det blev frem for alt i lovsangen, som ved Grundtvig tog et vældigt opsving, at den levende røst med hjerteklang kom til at lyde i den danske menighed. Det er svært for et folk med et andet modersmål at finde ind i Grundtvigs salmerigdom, selv om der i de senere år er gjort værdige forsøg på at oversætte dem, ikke blot til de nordiske broderfolk og de beslægtede engelske og tyske, men til en del andre, hvor det næsten må være et pinseunder, om de kan høre hjerteklangen deri.

Og af nærværende afhandling vil det fremgå, at det også er svært for danske at finde til bunds i det tankevæld, der strømmer gennem hans vers, helt uoverkommeligt at sammenfatte det alt til en klar lære, og derfor kun muligt ved poesiens og åndens sans at få et levende indtryk af, hvad han sagde, og hvad han ville dermed.

Men i den danske menighed og på den danske tunge skal hans sang lyde også i upoetiske tider, og kan vi blot høre røsten, skal også efterhånden tankerne klares eller dog $\mathrm{i}$ det mindste troen styrkes. 